\title{
Assessing Information Needs of Final Year Diploma Students at Kitale Polytechnic Library, Trans-Nzoia County, Kenya
}

\author{
Ambrose Nayombe Museve ${ }^{1}$, Ben Namande ${ }^{2}$ \\ ${ }^{1}$ Master of Library and Information Science Student, School of Education, Kenyatta University, \\ Kenya \\ ${ }^{2}$ Lecturer Department of Library and Information Science, Kenyatta University, Kenya
}

\begin{abstract}
This study assessed information needs of final year diploma students and the aspects explored were the adequacy, relevance, access and challenges faced in the use of the information resources. The study was limited to Kitale polytechnic library and the focus was the information that students seek to satisfy their information needs. The theory adopted for this study was the Principle of Least Effort that was developed by George Kengsley and explored in a study of library use of graduate students by Zao Lang.A descriptive research design was adopted to describe the level of students' information needs and use of the library. Qualitative method was used to collect textual data and quantitative method was used to collect numerical data. The target population of 426 library staff members and final year diploma students based on the polytechnic management records was purposively sampled for study. A sample size of 68 participants was selected for study. The main data collection tools were a structured questionnaire and an interview schedule which targeted students and key informants (library staff) respectively. Validity was sought by use of expert knowledge in the field of information science to ascertain accuracy of the research instruments and the split half method was used to achieve reliability of the instruments and information collected. Qualitative data was analyzed thematically while quantitative data was analyzed to generate percentages, frequency distribution tables and charts. The results established that majority of students need information for academic purposes while others use it for other information related requirements. The study also revealed that the library collection does not adequately cater for the information needs of students and it was further established that most of the library information resources are rarely relevant to students' information needs. The study concludes that most polytechnics are not keen on issues related to limited resources, staffing and the quality of information resources and services which negatively affect students in the library. The study recommended that polytechnic policy developers should formulate library policies that are not only academically inclined but also aimed at promoting other information related purposes. The study also recommended that the Institutional management should increase library allocation of resources to ensure improved equipping of a balanced library collection that addresses the diverse information needs of students. The study further recommended that polytechnic library management should enhance its acquisition policy to help acquire information resources from publishers that are more relevant to students' education and courses of study. The study should be useful to TVET department of the Ministry of Education in their quality assurance programs to formulate policies for polytechnics that maintain high standards of libraries and quality information services for students.
\end{abstract}

Key Words: Students' information needs, adequacy of library collection to meet students' information needs, relevance of library resources, challenges in meeting students' information needs 
DOI 10.35942/ijcab.v4i2.125

\section{Cite this Article:}

Museve, A., \& Namande, B. (2020). Assessing Information Needs of Final Year Diploma Students at Kitale Polytechnic Library, Trans-Nzoia County, Kenya. International Journal of Current Aspects, 4(2), 33-44. https://doi.org/10.35942/ijcab.v4i2.125

\section{Introduction}

Information needs are knowledge gaps that make an individual desire for information to be filled to reduce uncertainty. Albanese (2013) noted that polytechnic libraries should provide information services to seek for answers that are usually associated with suitable knowledge acquisition with a view to enhancing students' educational achievements. In this case, information should empower, allow for intellectual development and credibility for students. Therefore, information should be accurate, objective and timely to satisfy students' information needs. Final year students are a class that should exploit the library facility more than others because of the high demand of examinations and other related information.

Jillian (2010) reported that majority of polytechnic library users in Britain are final year diploma students. Donald (2012) explained that in U.S.A, polytechnic students' information needs require quality information services and this depends on the availability of sufficient information resources. Donald further stated that students need to browse appropriate library collections using the online sources of information and their satisfaction of information needs will determine the attitude towards the independent scholarly use of the information resources. Bhatti (2010) indicated that libraries need more clearly, easy to locate, reliable, accessible, meaningful and easily understood information to satisfy students' information needs. However, Branch (2011) pointed out that polytechnic libraries in Britain lack in-depth information resources and this has negatively affected the provision of information services to students. The above views are critical for polytechnics to help improve their libraries to satisfy students' information needs.

Zwarun (2009) noted that polytechnic library users in Pakistan need information resources that can enhance the provision of information services to meet the information needs of the library users. Zwarun further noted that for students to perform well and be competent in their fields of study, it is important that they access detailed subject coverage information resources. But, the situation shows that there is need for adequate library collection and personnel with the required skills and competencies to make it easy for polytechnics to satisfy students' information needs. Barbara (2012) in his study in India emphasized the need for training students not only on the use of ICT but also on the importance of attaining knowledge, information literacy, instructions and skills through the initiation of library user programs by the librarians. The use of ICT should enable users to access, store, transmit and manipulate information which is very useful in communication, learning and research. This ideally is to support objectives of the polytechnic in the area of students' information achievement and should be based on their understanding about information seeking behaviour with regard to the tools, preference for resources, language preference, informal channels of acquiring information and the satisfaction of information needs. These views emphasize the importance of skills by students to aid them in library usage.

Larson (2012) noted that students in Ghana rely on the available meager library resources to meet their information needs. Consequently, this has made the government to start supporting the polytechnics by equipping them with the necessary ICT infrastructure and information resources, 
leaving parent institutions to cater for the library manpower to provide library services to the students. Despite this effort, library information services are unsatisfactory and continue dwindling in Polytechnics. Tijani (2010) explained that in Nigeria, many students are admitted to polytechnics to promote academic standards in the country. To achieve this, the government sponsors students to undertake courses in TVET Institutions to boost technical skills and knowledge to better their academic achievement for the demanding job market in various technical fields. However, this has overstretched the use of available library information resources such as course books, primary literature and other e-resources due to the large number of students that use the library. Such views confirm why libraries need to boost their information resources to meet students' Information needs.

Mosha (2012) noted that although polytechnic students in Tanzania access and use the library, most of the stocked information resources are not relevant to the students' information needs since there is little indication to prove that they get the required information services as the students' usage of the library is not pleasing. The main interest is how libraries can provide appropriate information resources to satisfy students' information needs. Nzivo (2012) observed that in Kenya, the expectations of the polytechnic governing bodies such as TVET Authority are to develop training standards for polytechnic students. The Authority needs to create opportunities for youth to acquire technical skills, knowledge and values for not only their academics but also lifelong learning and other independent endeavors. For that reason, the curriculum needs to effectively address the information needs of the students, society and performance in the workplaces. The authority should also ensure that technical training matches expectations of industry. This can help align the sector with development ambitions of the country; hence assist the government in addressing the big four agenda which include: enhancing manufacturing, food security and nutrition, universal healthcare and affordable housing; for the benefit of students. However, these issues are yet to be effectively achieved in Kenya.

A research by the Ministry of Education, Kenya (2016) reported that polytechnic libraries are equipped by the government with information resources and ICT infrastructure. Moreover, many students are funded by the state to promote independent scholarly access and use of the information resources. But, the reality is that libraries still need to adequately satisfy students' information needs. This happens despite the substantial investment made by many polytechnics aimed at providing quality information services to students. Nyerere (2016) on his research about polytechnics in Kenya, basing on the Quality Assurance department report in the Ministry of Education, Science and Technology- Kenya, noted that library user satisfaction remains key as the quality of information services is wanting and there is low usage of the library by the students. This has subsequently affected the students' academics and other information requirements. In support of the above notion, Kavulya (2017) noted that the quality assurance programs underpinning technical education in Kenya need to stipulate a systematic review of educational programs and processes to make them objective, easily achievable and testable. The government needs proper policies, measures and actions to maintain and develop quality technical education and improve the library quality, equity and efficiency. This is certainly necessary to support the ongoing development of polytechnic teaching and learning to help meet the students' ever changing job market needs and demands. It was evident that a few studies had been carried out on students' information needs in Polytechnic Institutions. Therefore, the study assessed how Kitale Polytechnic library satisfies the information needs of final year diploma students. 


\section{Statement of the Problem}

The government of Kenya pumps in tax payers' money to equip and support Kitale polytechnic library. This is in terms of information resources and technological infrastructure; with an aim of satisfying students' information needs. However, the reality is that there is increasing concern regarding the adequacy, relevance and utilization of the library resources which prevents students from meeting their information needs. Based on these preceding issues, there are clear indications that provision of quality information services is a problem in the library. It was important to conduct this study since students need to appreciate the value of the library which positively impacts on their information needs and also influences other students in using the library.

\section{Objectives of the Study}

The objectives of the study were to:

i. Establish information needs of final year diploma students at Kitale National Polytechnic.

ii. Describe the adequacy of library collection to meet students' information needs.

iii. Assess the relevance of library resources to satisfy students' information needs.

iv. Find out the challenges faced by the final year diploma students in meeting their information needs.

\section{Theoretical and Conceptual Framework}

The principle of Least Effort theory has been adopted and considered relevant to guide this study. It was developed by George Kengsley in 1945. The theory bases information needs on use of most convenient, easy and familiar ways to access and achieve quality information by an information user. The principle was used by Zao Lang (2004) on graduate students and results revealed that learners who accessed and used relevant and adequate Information resources and services had easy ways and used minimal effort to satisfy their information needs. In this vein, this study showed that polytechnic libraries should have adequately relevant information resources to provide quality information services so that students can easily meet their information needs.

\section{Conceptual Framework.}

This section describes the interrelationship between the variables that were used in the study as shown in the diagram below. 


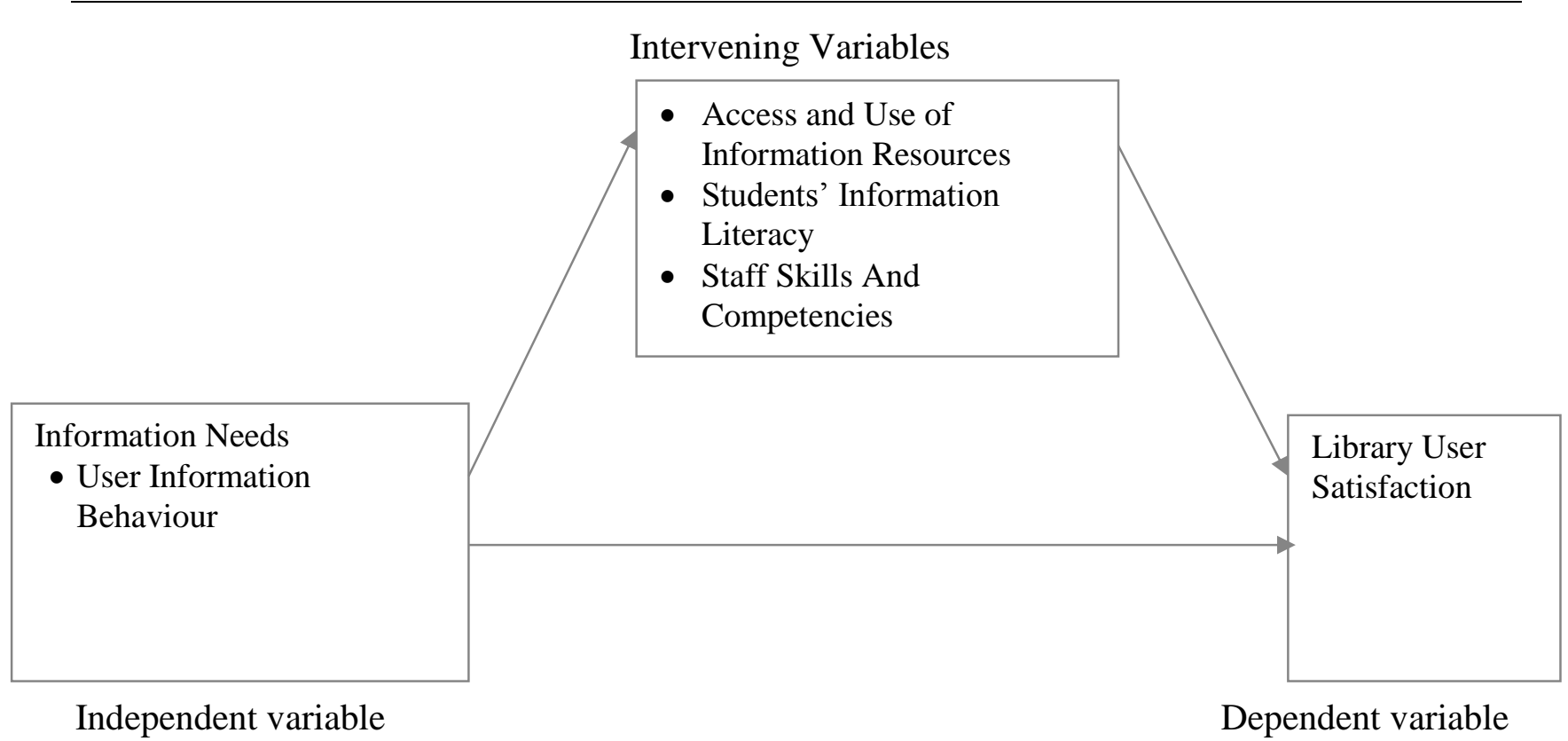

\section{Figure 1: Conceptual Framework}

In this study, the satisfaction of students' information needs highly depends on the adequacy of library collection and the relevance of library resources. Therefore, users' easy access and use of information, their information literacy skills and the support they require from the library staff are essential components for students to achieve quality information services from the library.

\section{Research Methodology}

The researcher adopted a descriptive research design. Ghauri (2012) defines descriptive research design as being concerned with assessment and description of a phenomenon and documentation of aspects of a situation which was used to generate knowledge for research. The researcher chose descriptive research design since this current study sought to assess, describe, document information needs and use of information resources by final year diploma students at Kitale polytechnic library. The researcher sought users' opinions, attitude and expectations about the library. Therefore, the researcher described the adequacy and relevance of information resources to the final year diploma students' information needs. The researcher used both qualitative and quantitative methods to collect data. Qualitative method was used to collect textual data by use of interview with the library staff. This method helped the researcher to probe the respondents to have a deeper insight into the students' information needs. Quantitative method was used to collect numerical data by administering questionnaires to students. This method allowed for broader study of responses for greater objectivity and accuracy of results.

The study locale was Kitale National Polytechnic Library, Trans-Nzoia County, Kenya. The polytechnic was selected because it was the only institution of higher learning in the County, with a high population of students, offering a variety of courses and is in a cosmopolitan region. This meant it was interesting to study the varied information needs of students due to students' varied environmental and cultural backgrounds, thus in-depth study. A background check indicated that the other established tertiary academic institutions, that is, Moi University campus and Mt.Kenya University campus which also used to offer some diploma courses ceased to operate. 
Target population contains members of a group that a researcher is interested in studying. The target population for this study was formed by the library staff and final year diploma students of Kitale National Polytechnic obtained from the Institutions' management records of 2019. The records provided a total target population of 5 library staff and 421 students doing final year diploma courses at the institution.

The study utilized purposive sampling to select library staff and final year diploma students for sampling. Robson (2012) explains that purposive sampling is a technique in which a researcher's own judgment is relied on when choosing members of population to participate in the study. The researcher selected library staff, due to their experience and job qualifications; they have knowledge and skills and are in a position to understand information needs, access and use of information resources by students. On the other hand, final year diploma students were purposively sampled given the fact that the students were studying in their final year, it meant this was a class that used information resources more for their academics hence had relevant information pertaining their information needs they sought to satisfy which is relevant to this study. Qualitative data was analyzed thematically while quantitative data was analyzed to generate frequency distribution percentages, tables, charts and graphs for ease of understanding and interpretation.

\section{Data Analysis Results}

The study investigated the students' information needs. The five library staff respondents were asked to explain what information students sought from the library. The data collected is presented below. Three respondents said that, "students mostly seek academic information". One staff member said that, "students come to the library to research on new ideas." Another one library staff asserted that, "some students seek entertainment information from the library ; they seek entertainment information e.g. sports and beauty to release stress after class work". (Researcher's Fieldwork, 2019).This shows that students seek information related to academic, research and entertainment from the library. Akporhonor (2007) agrees with these views for he stated that students in many cases use libraries for information that ranges from academic, research and entertainment purposes.

The study investigated the information the students sought from the library. The respondents were asked to indicate what information they sought from the library. The data collected from students is indicated in Figure 2 below. 


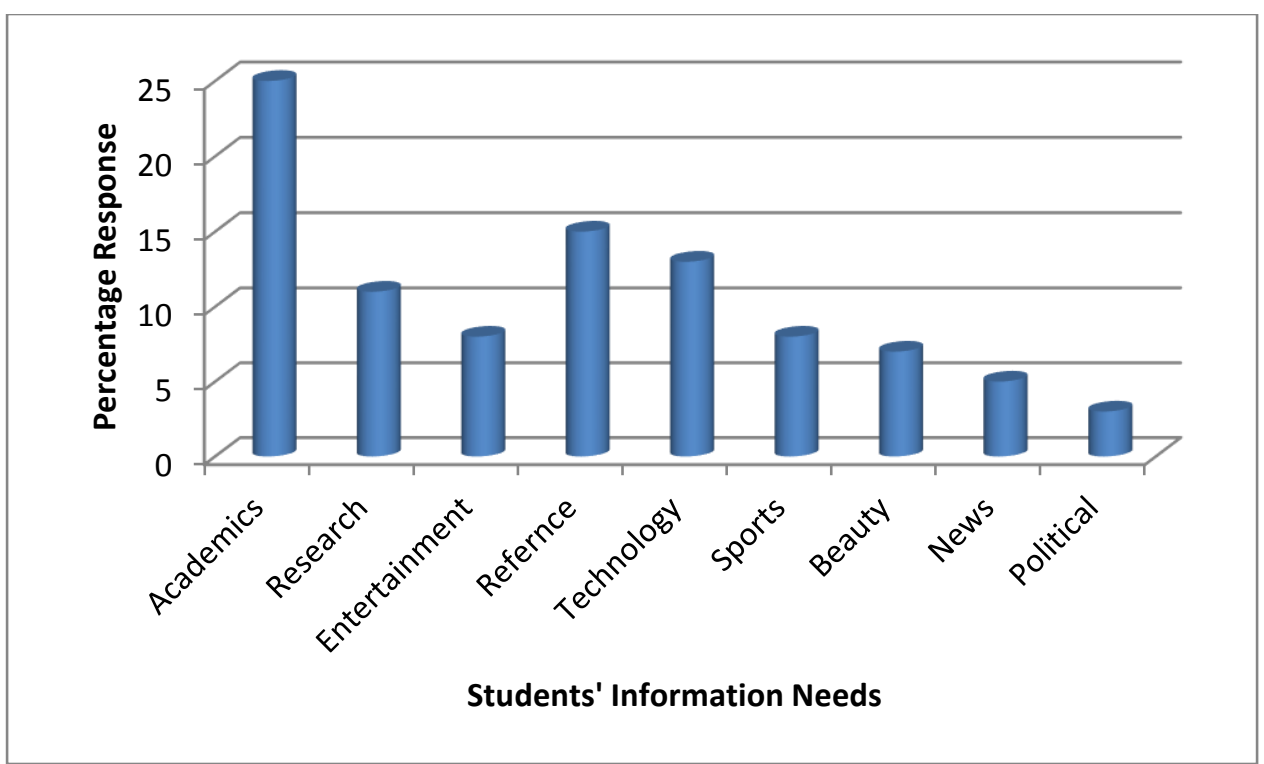

Source: Researcher's Fieldwork, 2019

Figure 2: Students' response on information sought

Data collected from respondents indicated that out of the 63 respondents, $15,(25 \%)$ of the students stated that they sought academic information,6,(11\%) looked for research related information,5,(8\%) used the library for entertainment,9, $(15 \%)$ visited it for reference purposes. Moreover, $8,(13 \%)$ sought technology related information,5(8\%) watched sports, 4(7\%) sought for beauty related information,3(5\%) looked for news and 2 (3\%) sought for political information. The findings of this study indicated that students seek a variety of information from the library which include academic, entertainment, research and references .Others are technology, sports, beauty, news and political related information. This in line with Oduwole (2017) views who explained that students mostly use libraries for varying reasons such as seeking academic information, research, technology, reference, news and entertainment among others.

The study investigated the adequacy of the library collection. The library staff respondents were asked to indicate how adequate is the library collection in meeting students' information needs. All respondents showed their concern over the limited library collection. Frequently used terms by the interviewees were 'not sufficient', 'inadequate' or 'not enough'. Two respondents opined that, 'most of the existing collection is inadequate, the copies are not enough for the students especially key course books'. One respondent underlined that, 'there is need for more information resources on technical subjects such as Electrical Engineering, Mechanical Engineering and Agricultural Engineering and provision of books on general knowledge and other general areas of interest'. Another participant said that, 'journals collection are not

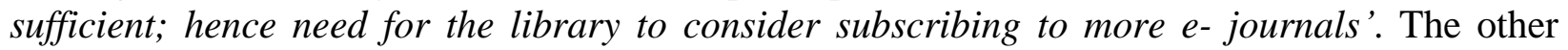
participant urged that, 'the library management needs to enhance the CDs collection and the provision of internet access in the library. ' (Researcher's Fieldwork, 2019).

This shows that adequacy of library collection has issues and is a great concern for libraries. This is similar with the views of Golafshani (2015) who explained that adequacy of the polytechnic library collections have issues which include fewer copies of key books, technical subjects, general areas of interest, less access to internet and subscription to e-journals ; these negatively 
affect students in meeting their information needs.

The study sought to establish the library user satisfaction. The library staff respondents were asked to indicate the user satisfaction levels of students about the usage of library information resources. The data collected is presented below. Two respondents indicated that 'students are highly satisfied with the library services since timely library services are provided to users.' Two other respondents opined that, 'students are moderately satisfied with the library services since they regularly use the library.' Another respondent said, 'students are lowly satisfied since the library collection is not very balanced'. This shows that some library user satisfaction is achieved in the library. (Researcher's Fieldwork, 2019). This is in line with Latha (2017) who commented that library user satisfaction can be achieved through the provision of timely library services, regular use of the library and access to a balanced library collection by students.

The study assessed the relevance of library resources to satisfy students' information needs. The library staff respondents were asked to state how adequate is the library collection in meeting students' information needs. The data is presented below. The staff respondents were asked to explain how relevant were the information resources to students' information needs One respondents said, 'the information resources are not very appropriate and current". Two respondents indicated that, 'most of the information resources are not obtained from reputable scholars and are not authoritative.' Two other respondents asserted that, 'most of the library information resources are obsolete.' (Researcher's Fieldwork,2019). This shows that most of the information resources are not relevant to students' information needs. This is in line with Kulp (2011) who noted that most of the polytechnic library resources in Kenya are old stock, obsolete non-authoritative and non reputable scholarly works and thus not very relevant for students in their pursuit of information.

The study sought to find out the challenges faced by the library staff in providing information services to students. The staff respondents were asked to explain what are the challenges facing the staff in providing information services to students. Two library staff members said, " the library lacks enough information resources." Two other staff members said, "most of the information resources are old and obsolete." The other one library staff mentioned that, 'there is no proper motivation to work among the staff members'. (Researcher's Fieldwork,2019). This shows that there are varied challenges faced by the library staff in providing information services to students. This is in line with Allison (2015) views who argued that libraries are faced by various challenges in providing information services to students which include working with scarce resources, obsolete information resources and lack of motivation, and all these negatively affect the library staff in the provision of library services.

The study examined the challenges faced by students in pursuit of information. The student respondents were therefore asked to indicate the challenges they face when seeking for information to meet their information needs. Data collected from respondents' questionnaires are indicated in Figure 3 below. 


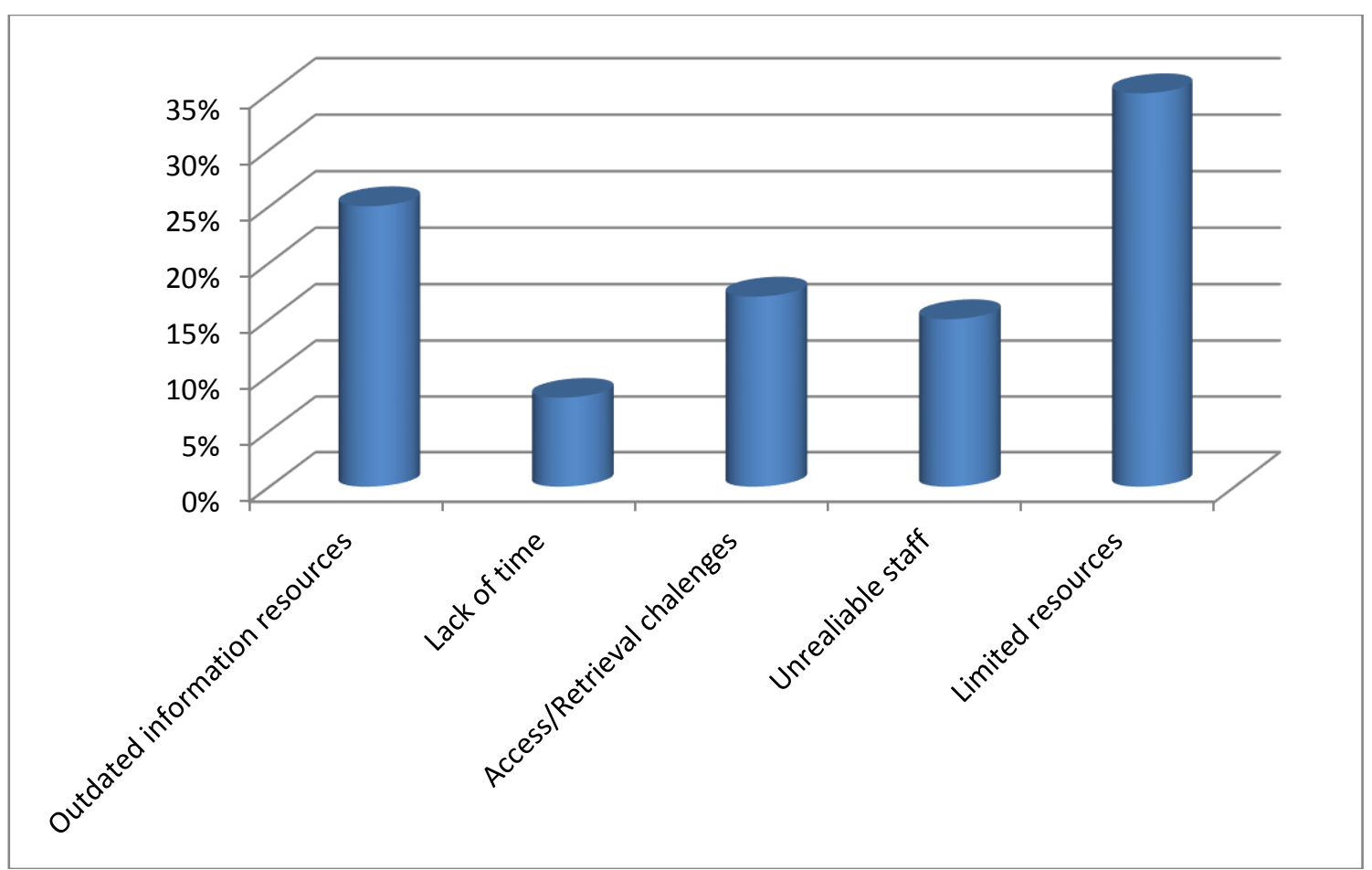

\section{Source: Researcher's Fieldwork, 2019}

\section{Figure 3: Students' response on the challenges faced}

Data collected from the 63 respondents indicated that the students faced varied challenges which include: 15 (25\%) Outdated information resources, 5(8\%)lack of time, 11(17\%) access/retrieval challenges, 10(15\%) unreliable staff and22 (35\%) limited resources. The data collected indicated wide disparity of challenges faced by students in the library. This is in agreement with Casado (2016) who observed that obsolete library stock ,limited resources, access and retrieval issues are some of the critical challenges faced by learners in libraries. The study established the solutions to the problems facing the staff in the library. The staff respondents were asked to explain the solutions to the challenges facing the library staff in providing services to the students in the library. The data collected is presented below. Two library staff members sated that, "the library should increase resources ;especially the e-resources such as the introduction of Wi-Fi services". The other two staff members said that, "the library should acquire more current and useful resources". One library staff member said that the "the library staff should be remunerated, motivated and given regular refresher courses." (Researcher's Fieldwork,2019). This shows that solutions to the challenges facing the library staff include by the staff include need for more adequate and relevant library collection. It is also necessary to motivate the staff for better information service provision. This is in line with Lawal (2013) who opined that library staff require more current, useful information resources and good motivation to foster the efficiency in the provision of information services to students.

The study examined the solutions to the challenges faced by students in pursuit of information. Respondents were therefore asked to indicate the challenges they face when seeking for information to meet their information needs. Data collected is indicated in Figure 4 below. 


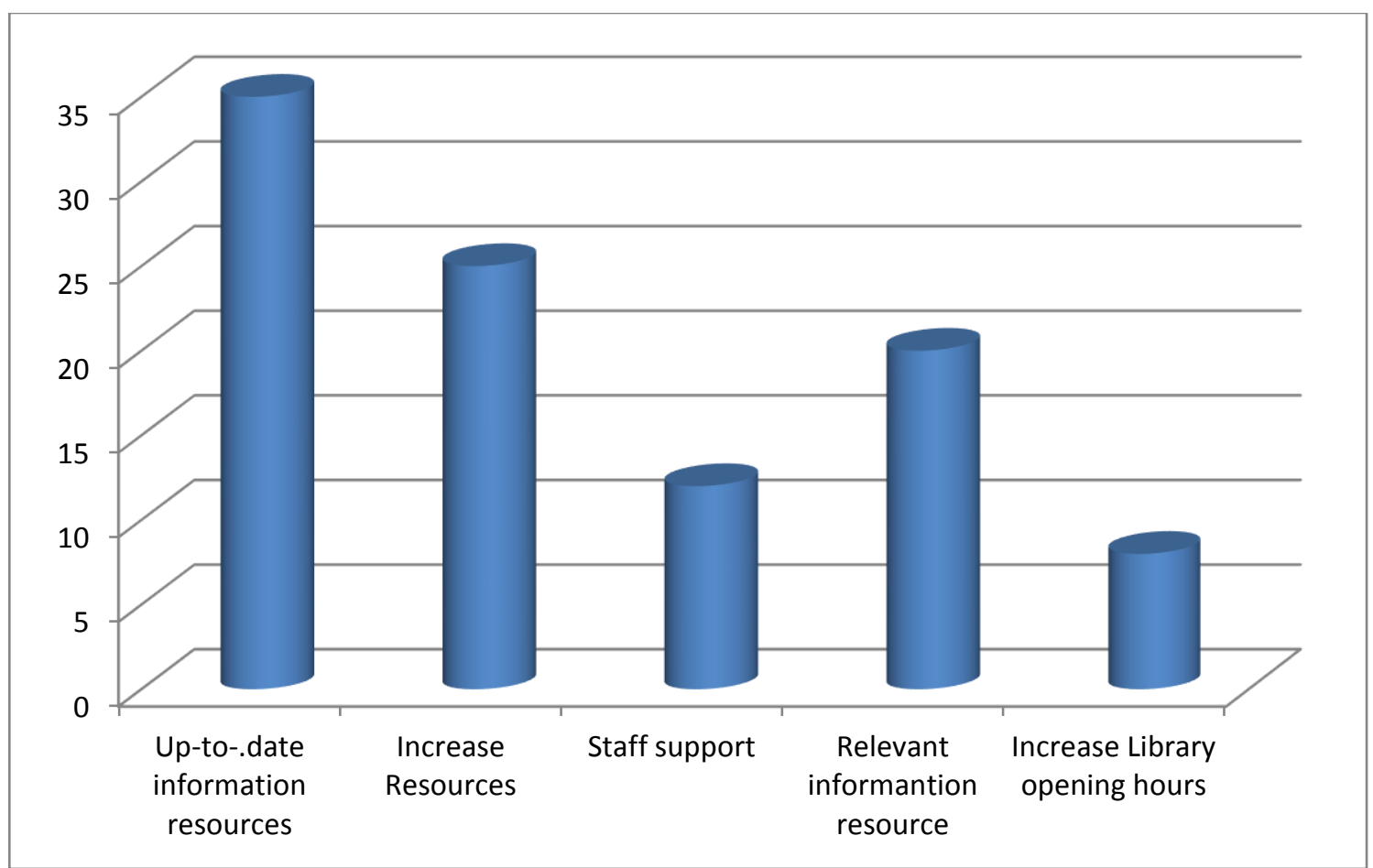

\section{Sources: Researcher's Fieldwork, 2019}

Figure 4: Students' response on solutions to the challenges faced (\%)

Data collected from 63 respondents indicated that 22 (35\%) needed up-to-date library resources, $15(25 \%)$ increase resources especially the e-resources, $8(12 \%)$ asked for support from staff when accessing and retrieving information, $12(20 \%)$ needed more relevant resources and $6(08 \%)$ increase in library opening hours. This shows that solutions to the challenges facing students in their pursuit of information include need for up-to-date information resources, increased resources, staff support, need for more relevant information resources and improved library time. In support of these views, Watters (2013) reported that polytechnics can improve provision of information services through updated information, increased resources, more relevant information resources and support from the library staff.

\section{Conclusion}

The study concludes that in the light of the above research findings, information needs of students are inclined towards academics and other related information. With the increase in demand for information by students, it is imperative that polytechnics can rarely cater for their libraries and users' information needs. Polytechnics are not keen on issues related to limited resources, staffing and quality of information resources and services. To this end, libraries continue to pursue for ways to adequately satisfy students' information needs.

\section{Recommendations}

The study is crucial to the polytechnic policy developers. They should use research to formulate library policies that are not only academically inclined but also aimed at promoting other information related requirements to foster students' all round talents in line with their information needs. The study should assist the Institutional management to increase library 
allocation of resources to ensure improved equipping of a balanced library collection that addresses the diverse information that satisfies a variety of students' information needs. The Polytechnic library management should enhance its acquisition policy to help acquire information resources from publishers that are more relevant to students' education and courses of study to satisfy their information needs. The study has implications to the polytechnic management whereby the library staff should undergo training to equip them with the necessary knowledge, skills, attitudes and competencies in library programs aimed at improving and providing quality information services to satisfy students' information needs. The study should be useful to TVET department of the Ministry of Education in their quality assurance programs to formulate and prioritize policies for polytechnics that maintain high standards of libraries and quality information services in line with the ever changing students' information needs. The government policy ministry should formulate proper institution-programs that are curriculum based and geared towards making students holistic scholarly for the competitive job, market and industry demands.

\section{REFERENCES}

Akporhonor, C. (2014).Library impact data project: Looking for the link between library usage and student attainment. College and Research libraries. 74 (6), 546-559.

Albanese ,K. (2013). Problem-based learning ; a review of literature on its outcomes and implementation issues .Academic Medicine.Journal of the Association of American Medical Colleges ,68 (1),5281 .

Allison, K. (2015).The effect of Information literacy on the utilization of electronic information resources.Retrievedfromhttp://www.emeraldinsight.com./journalshttm?Issn=02640473\&amp:Iss ue $=3 \&$ articidcid $=1610818=$ abstract.

Barbara, V. (2012).The Legitimate effort in research papers Student commitment versus faculty expectations. The Journal of Academic Librarianship, 27(2), 107-115.

Bhatti, R. (2010).Information needs and information seeking behaviour of faculty members of Technical College.Library philosophy:http:digitalcommons.unl.edu/libphilprac/314.

Branch, J. (2011).An Examination of Information Seeking Behaviour and the Impact of Literacy Instructions. Journal of Research Strategies, 17(1), 3-15.

Casado, M. (2012).Delivering library services with Central symposium .Journal of Library Administration,37(2),127-135.Available at:www.emeraldinsight.com/0307-4803.html.

Donald, O. (2012). Information Seeking, Needs and Behaviour. San Diego, CA: Academic Press.

Ghauri, P. (2012). Research Methods in Business Studies. Harrow, England: Prentice Hall.

Golafshani , J .(2015) .Learning from teaching ; exploring the relationship between reform curriculum and equity. Journal for research in Education, 33 (4),239-258 .

Jillian, R. (2010).Students' Searching Behaviour and the Website: Use of Academic Resources. Journal of Library trends, 53(4), 539-554).

Kavulya, N. (2017). Effectiveness of polytechnic libraries in Nigeria. Journal of Librarianship and Information Science in Africa, 11(4), 43-48.

Kingsley, G. (1945).Human Behaviour and the Principle of Least Effort. Addison:Wesley press.

Kulp, C. (2011).The Information seeking habits of engineering faculty. Research libraries, 72 (6), 548567.

Lang, B.(2004).Students information literacy standards for higher education. Chicago: American Library Association.

Larson, A. (2012).Use of social media and its impact on academic performance of students: a study of Kofaridua polytechnic .Journal of Education and practice,4(6), 694-100. 
Latha, G. (2017).Doing your research project: a student guide for first time researchers :education and social sciences. New Delhi : Viva Books private limited.

Lawal, L. (2013).Transaction log analyses of electronic book usage. Journal of Librarianship, 32 (2),323330.Retrieved from http://.oclc.org/research/publications/archive/connaway-snyder- atg.pdf.

Ministry of Education(2016).The Development of Education:National Report of Kenya.Nairobi: Ministry of Education.

Mosha, N. (2012).Health Information Seeking Behaviour among Polytechnic Students in Kilimanjaro Region-Tanzania. Scholarly Journal of Librarianship, 1(.4), 80-93.

Nyerere, J. (2016).Technical and Vocational Education and Training (TVET): Sector Mapping in Kenya .Amersfoort: Edukans Foundation.

Nzivo, C. (2012).Use Perception on Library services and information resources. Library Review,60 (4), 115-1130.

Oduwole, K. (2007).Bringing users back to the library. New library world, 107(3), 432- 445.Retrieved from http://emeraldinsight.com/0307-4803.html.

Robson, R. ( 2012). Seamless library user experience.Sydney:Step Two Designs PTY Limited.

Robson, C. (2002). Real World Research. (2 ${ }^{\text {nd }}$. ed.).USA:Blackwell publishing.

Tijani , K. (2010).Internet Usage among Nigerian Polytechnic Students and Its Impact on Man Power Development: A Case Study Approach. Journal of Information Technology Impact, 10(1), 161170.

Watters, G. (2013). A Survey on the use of electronic databases and journals accessed through the web by the academic staff of Israel Universities. The Journal of Academic Librarianship, 29 (6),346-361.

Zwarun, L. (2009).College Student Web Use Perception of Information Credibility and

Verification Behavior .Journal of Computer and Education,41(3),271-290

This is an open-access article published and distributed under the terms and conditions of

the (c) States unless otherwise stated. Access, citation and distribution of this article is allowed with full recognition of the authors and the source.

Authors seeking to publish with an Internationally Peer Reviewed Journals should consider https://www.ijcab.org/ by writing to the Editor at editor@ijicab.org or submitting online at https://journals.ijcab.org/journals/index.php. The articles must be quality and meet originality test.

$\frac{\text { IJCAB }}{\text { Publishing Group }}$ 